\title{
Notes on Potentilla L. (Rosaceae) of Altai. 5. A new intersectional hybrid from Central Altai
}

\author{
A. A. Kechaykin \\ South-Siberian Botanical Garden, Altai State University, Lenina pr. 61, Barnaul, 656049, Russia \\ E-mail: alekseikechaikin@mail.ru
}

Key words: Altai Republic, nothospecies nova, Potentilla $\times$ chemalense.

Summary. A new nothospesies of Potentilla, $P . \times$ chemalense, from Central Altai is described and illustrated. It is an intersectional hybrid purportedly between $P$. chrysantha ( $P$. sect. Chrysanthae) and $P$. tanacetifolia $(P$. sect. Tanacetifoliae). The plant was found in the Chemalsky district in the Katun river valley (middle reaches). $P . \times$ chemalense grows on steppe-like stony southern-exposed slopes with shrub thickets. The morphological characters of the new nothospecies $P . \times$ chemalense are compared with those of related species. $P . \times$ chemalense is distinguished from $P$. chrysantha by pinnate leaves and from $P$. tanacetifolia by smaller number of pairs of lateral leaflets. The presence in $P$. $\times$ chemalense petiole of terminal leaflet makes it closer to $P$. tanacetifolia.

\section{Заметки о лапчатках (Potentilla, Rosaceae) Алтая. 5. Новый межсекционный гибрид из Центрального Алтая}

\author{
А. А. Кечайкин \\ Южно-Сибирский ботанический сад, Алтайский государственный университет, пр. Ленина, 61, г. Барнаул, \\ 656049, Россия.E-mail: alekseikechaikin@mail.ru
}

Ключевые слова: новый нотовид, Республика Алтай, Potentilla × chemalense.

Аннотация. Приводятся описание и иллюстрации нового для науки нотовида из рода Potentilla. Собранный на территории Центрального Алтая $P . \times$ chemalense представляет собой межсекционный гибрид $P$. chrysantha $(P$. sect. Chrysanthae $) \times P$. tanacetifolia $(P$. sect. Tanacetifoliae). Растение обнаружено в Чемальском районе в долине реки Катунь (среднее течение). Potentilla $\times$ chemalense произрастает на остепненных каменистых склонах южных экспозиций среди зарослей кустарников. Сравниваются морфологические характеристики нового нотовида $P$. $\times$ chemalense и родственных таксонов. Перистые листовые пластинки отличают $P . \times$ chemalense от P. chrysantha, а меньшее число пар боковых листочков - от P. tanacetifolia. Наличие у P. $\times$ chemalense черешка верхушечного листочка сближает ее с P. tanacetifolia.

\section{Introduction}

As a result of the field work in the territory of Central Altai, the scientists from South Siberian Botanical Garden discovered an interesting taxon from the genus Potentilla L. Its population, which numbers several tens of individuals, was found in one of the valleys of the Katun river basin. This species has been found so far in Chemalsky district of the Altai Republic only, and hence we named it Potentilla $\times$ chemalense. This hybrid is supposed to have originated through hybridization between $P$. tanacetifolia Willd. ex D. F. K. Schltdl. and P. chrysantha Trevir. Its description and affinity are provided below.

\section{Taxonomic treatment}

Potentilla $\times$ chemalense Kechaykin, nothosp. nov.; P. tanacetifolia Willd. ex D. F. K. Schltdl. $\times$ P. chrysantha Trevir. (Fig. 1). 
Type: "Russia, Altai Republic, Chemalsky district, the Katun river valley, right bank, $6 \mathrm{~km}$ from the mouth up the Biyka river, stepped slopes and mixed forest. N51.1105 $, \mathrm{E} 86.1218^{\circ}, 750-820 \mathrm{~m}$ a. s. 1.19 VI 2016. Kechaykin A. A., Kopytina T. M." (ALTB; iso - ALTB, B, LE, MW).

\section{Diagnosis}

Planta perennis ad $75 \mathrm{~cm}$ alta, superne glandulis magnis copiosis obsita. Caules 2-4(5), adscendentes vel erecti, multiflori. Folia radicalia pinnata, 10-35 cm longa, longe-petiolata, 3-4-juga. Foliola lateralia sessilia, terminale petiolatum; omnia lanceolata, pinnatifido-serrata. Stipulae foliorum laciniatae. Inflorescentia subcorymbosa. Corolla laete lutea. Petala rotundata, emarginata, calyce sesqui longiora.

\section{Description}

Large perennial plants $30-75 \mathrm{~cm}$ tall. Basal leaves $10-35 \mathrm{~cm}$ long, lower and middle cauline leaves $4-15 \mathrm{~cm}$ long. Leaflets typically $2-5.5 \mathrm{~cm}$ long. Basal, lower and middle cauline leaves with 3-4 pairs of leaflets. Leaflets of the lower pair much smaller than the others, $1-1.5 \mathrm{~cm}$ long. Upper cauline leaves with 2 pairs of leaflets, ternate or simple. Leaflets saw-toothed with 4-8 teeth on both sides, and the terminal leaflet sometimes with 9-11 teeth. Leaflets of the lowest pair with 2-3 teeth on both sides incised into 2-3 lobes, often entire. Terminal leaflet of the leaf blade with a petiole $2-15 \mathrm{~mm}$ long. The distance between pairs of leaves typically $2-10$ $\mathrm{mm}$. Lowest pair often distant onto $2-3.5 \mathrm{~cm}$ from the rest of pairs (character mainly of basal and lower cauline leaves). Stipules of basal and lower cauline leaves 2-4 cm long, with lanceolate, elongate, acute-pointed entire auricles. Stipules of the middle and upper leaves $(0.5-) 0.7-2(-2.5) \mathrm{cm}$ long with broad auricles deeply incised into 2-4 sharp teeth. Stems and petioles of leaves in the lower part of the plant covered with squarrose crisped hairs $2-3 \mathrm{~mm}$ long and small transparent stalked glandules. In addition to long curved hairs, stalks and petioles in the middle and upper parts covered with short crisped hairs. Leaflets pubescent with sparse short bristly hairs above, beneath covered with longer crisped hairs along veins. Stipules glabrous or covered with single short bristly hairs above. Upper part of plant abundantly covered with large stalked yellowish glands. Flowers numerous, $1.2-1.5 \mathrm{~cm}$ in diameter, aggregated in corymbose inflorescences. Petals rotund with a notch, bright yellow, 1.5 times the size of calyx. External lanceolate sepals (epicalyx) equal or 1.5 times longer than narrowly triangular inner ones (calyx). Stamens 20, arranged in three whorls. Anthers oval. Styles baculiform, 1.2-1.5 mm long, slightly enlarged at base, with an enlarged stigma. Mature nuts 1.7-2 mm long, with subtle longitudinal wrinkles.

Distribution. The plant was found in the southeastern part of West Siberia in the Katun river valley (middle reaches). According to "Flora of Altai" (Kamelin, 2005), locus classicus of $P . \times$ chemalense is restricted to the Altai-West Sayan mountain province and according to A. V. Kuminova (1960) it grows in Central Altai.

Ecology. $P . \times$ chemalense is a xerophyte that prefers steppe-like stony southern-exposed slopes with shrub thickets (Fig. 2B). The plant was found among the populations of $P$. chrysantha (Sect Chrysanthae (Lehm.) Juz.) and P. tanacetifolia (sect. Tanacetifoliae (Lehm.) Juz.). Therefore, these species can be assumed to be parental for P. $\times$ chemalense.

Etymology. The species is named according to the area of its distribution (Chemalsky district).

Affinity. $P . \times$ chemalense is close to only two taxa, $P . \times$ nebulosa Danihelka et Soják and $P$. $\times$ jakovlevii Kechaykin et Shmakov, both described from the Altai mountain country. $P . \times n e b u$ losa was found in the Dzhazator river valley (Altai Republic, upper Katun river basin). According to the authors, it is a hybridogenic species originated through hybridization between $P$. chrysantha and $P$. pensylvanica L. (sect. Multifidae (Lehm.) A. Nelson) (Danihelka, Soják, 2012). P. × jakovlevii, a hybrid between $P$. chrysantha Trevir. and P. longifolia (sect. Tanacetifoliae) (Kechaykin, Shmakov, 2014), was first found in the mountains of the Narym mountain range on the territory of the Republic of Kazakhstan (East Kazakhstan region, the Maimyr river valley). Thus, $P$. chrysantha is one of the parental species of $P . \times$ chemalense and the two closely related hybrids mentioned above. Unlike $P . \times$ nebulosa and $P . \times$ jakovlevii, the terminal leaflet in $P$. $\times$ chemalense has a petiole that makes it closer to P. tanacetifolia (Fig. 2A). The major diagnostic features to distinguish $P$. $\times$ chemalense from the close taxa are given in Table.

Acknowledgements. The author is grateful to Viktoria Severina for making the illustration of the new taxon. This article was prepared with the support of state assignment (project № 6.5498.2017/8.9). 


\begin{tabular}{|c|c|c|c|c|c|c|c|}
\hline & 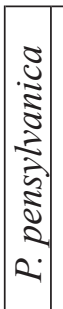 & 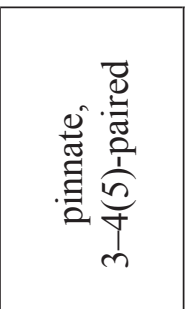 & 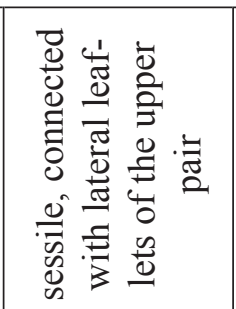 & $\stackrel{n}{I}$ & 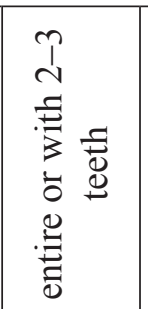 & 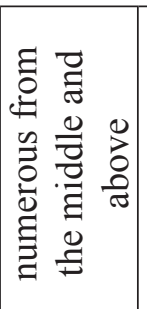 & 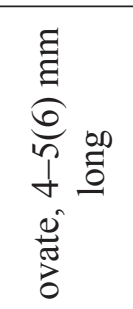 \\
\hline & 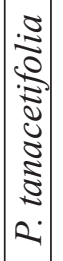 & 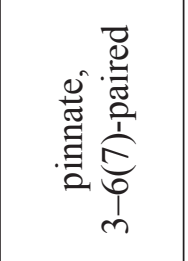 & $\begin{array}{l}\frac{0}{\pi} \\
\frac{\pi}{\Xi} \\
.0 \\
0 \\
0\end{array}$ & $\underset{\sim}{+}$ & 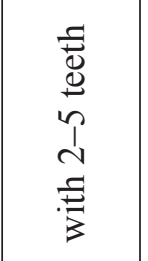 & 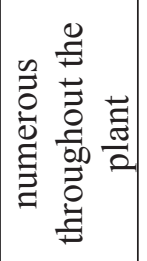 & 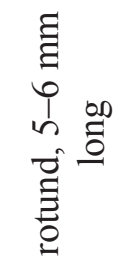 \\
\hline 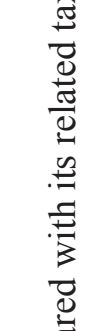 & 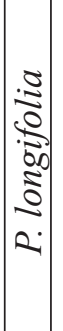 & 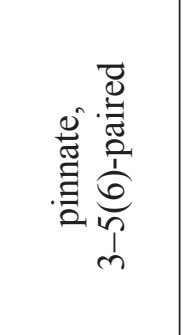 & 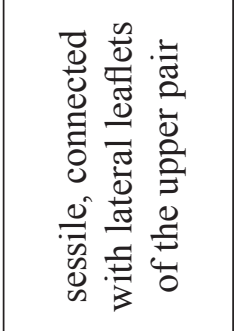 & $I$ & 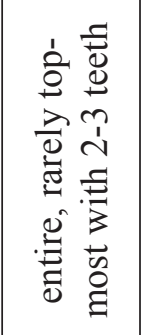 & 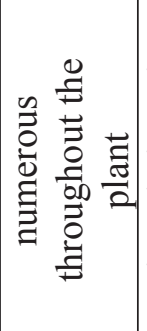 & 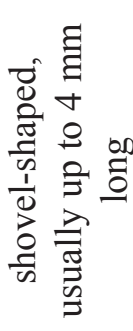 \\
\hline 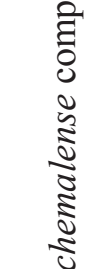 & $\mid \begin{array}{c}0 \\
0 \\
\vdots \\
\vdots \\
\vdots \\
\vdots \\
\vdots \\
x \\
2 \\
2\end{array}$ & 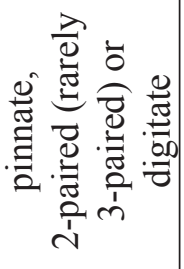 & 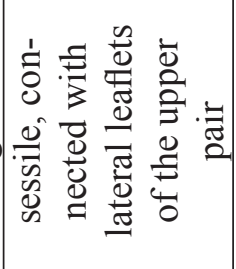 & $\begin{array}{l}\text { In } \\
n \\
\end{array}$ & .气 & 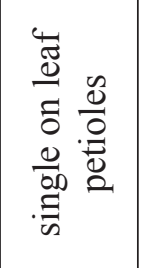 & $\begin{array}{l}\tilde{z} \\
\text { 亲 } \\
\Xi\end{array}$ \\
\hline 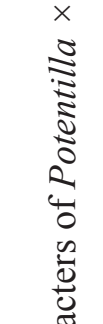 & $\mid \begin{array}{c}0 \\
\vdots \\
0 \\
0 \\
\vdots \\
\vdots \\
0 \\
0 \\
x \\
2\end{array}$ & 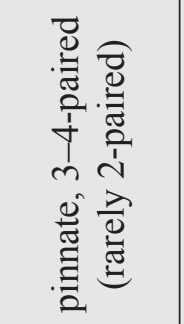 & 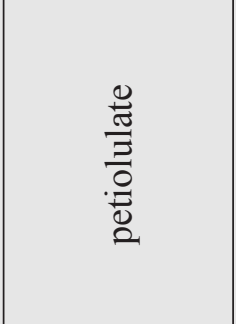 & 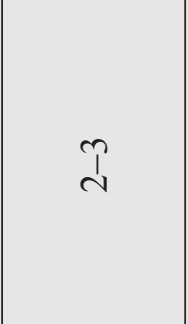 & 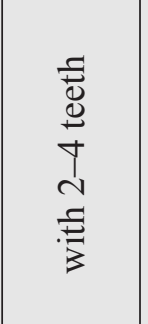 & 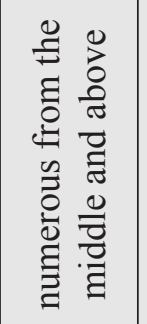 & 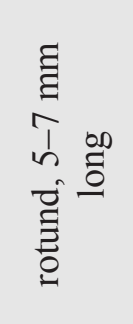 \\
\hline 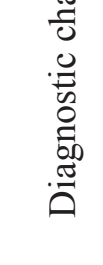 & 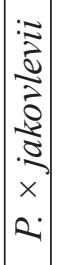 & 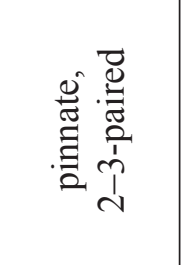 & 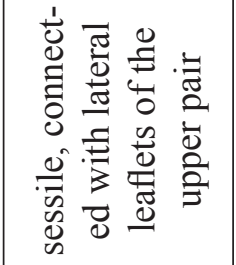 & $\begin{array}{l}\text { N } \\
n \\
-1\end{array}$ & 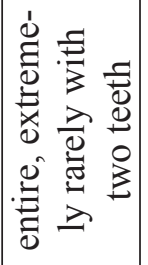 & 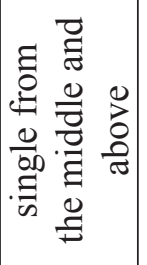 & 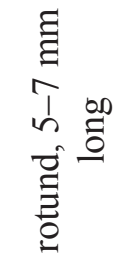 \\
\hline & $\mid$\begin{tabular}{c|}
0 \\
0 \\
$\vdots$ \\
$\vdots$ \\
0 \\
5 \\
0 \\
2 \\
2
\end{tabular} & $\begin{array}{l}\frac{0}{0.0} \\
.00 \\
.0\end{array}$ & 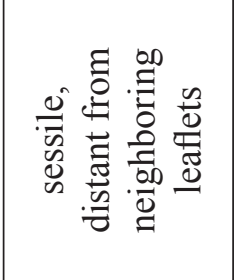 & $\begin{array}{l}\text { N } \\
n \\
-\end{array}$ & 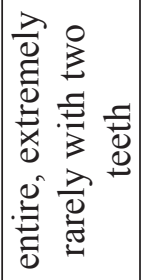 & 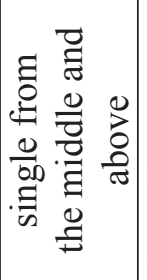 & 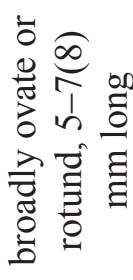 \\
\hline & 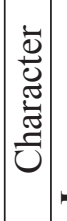 & 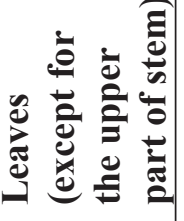 & 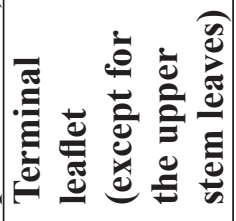 & 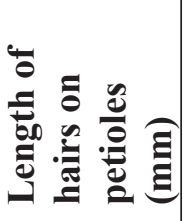 & 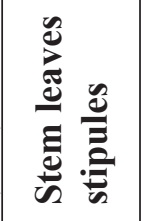 & $\frac{\stackrel{0}{E}}{\frac{E}{E}}$ & $\begin{array}{l}\frac{n}{\pi} \\
\text { L } \\
\text { L }\end{array}$ \\
\hline
\end{tabular}




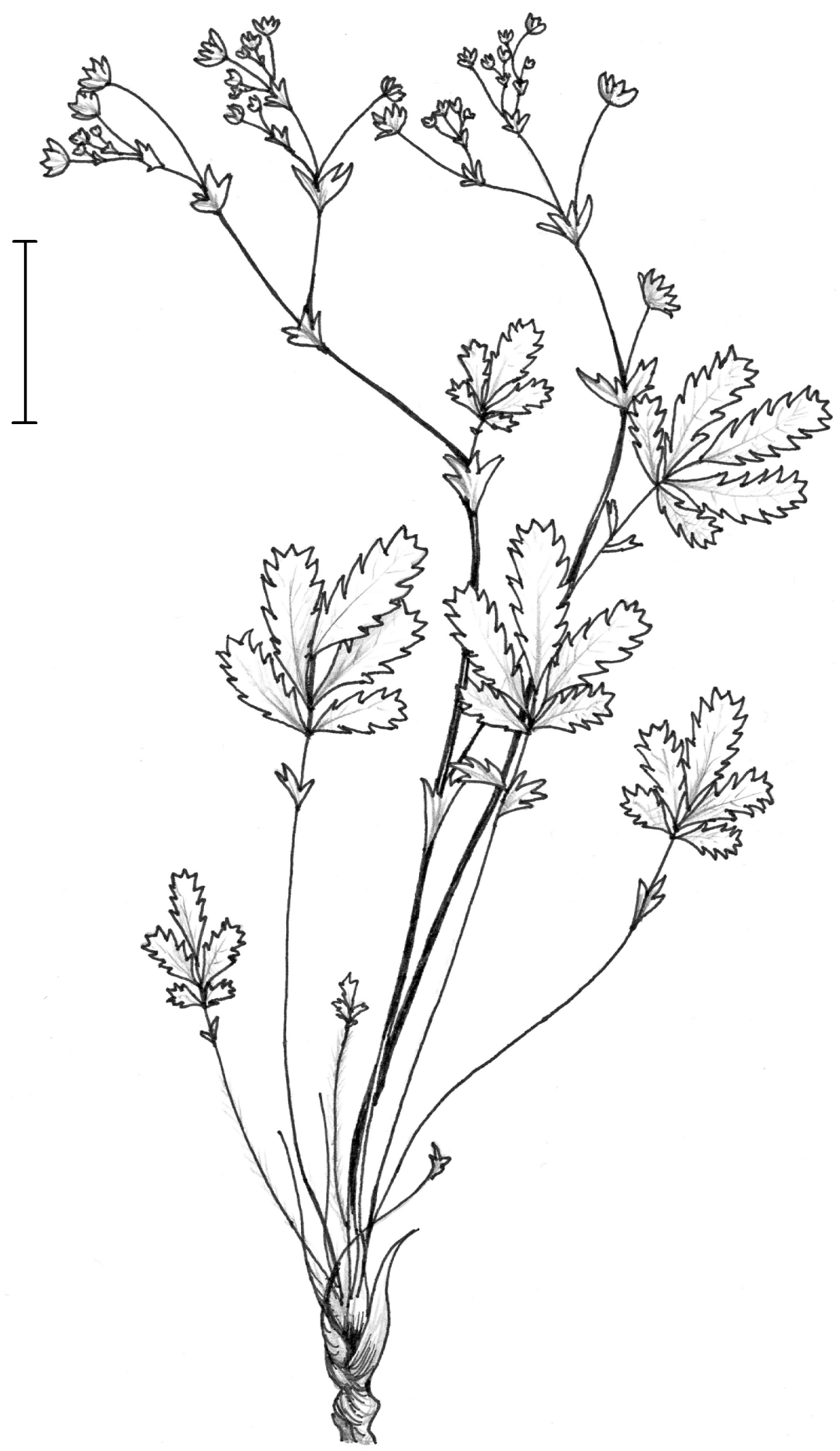

Fig. 1. Potentilla $\times$ chemalense, nothosp. nov. Scale bar: $4 \mathrm{~cm}$. Drawn by V. Severina based on type material from Central Altai. 

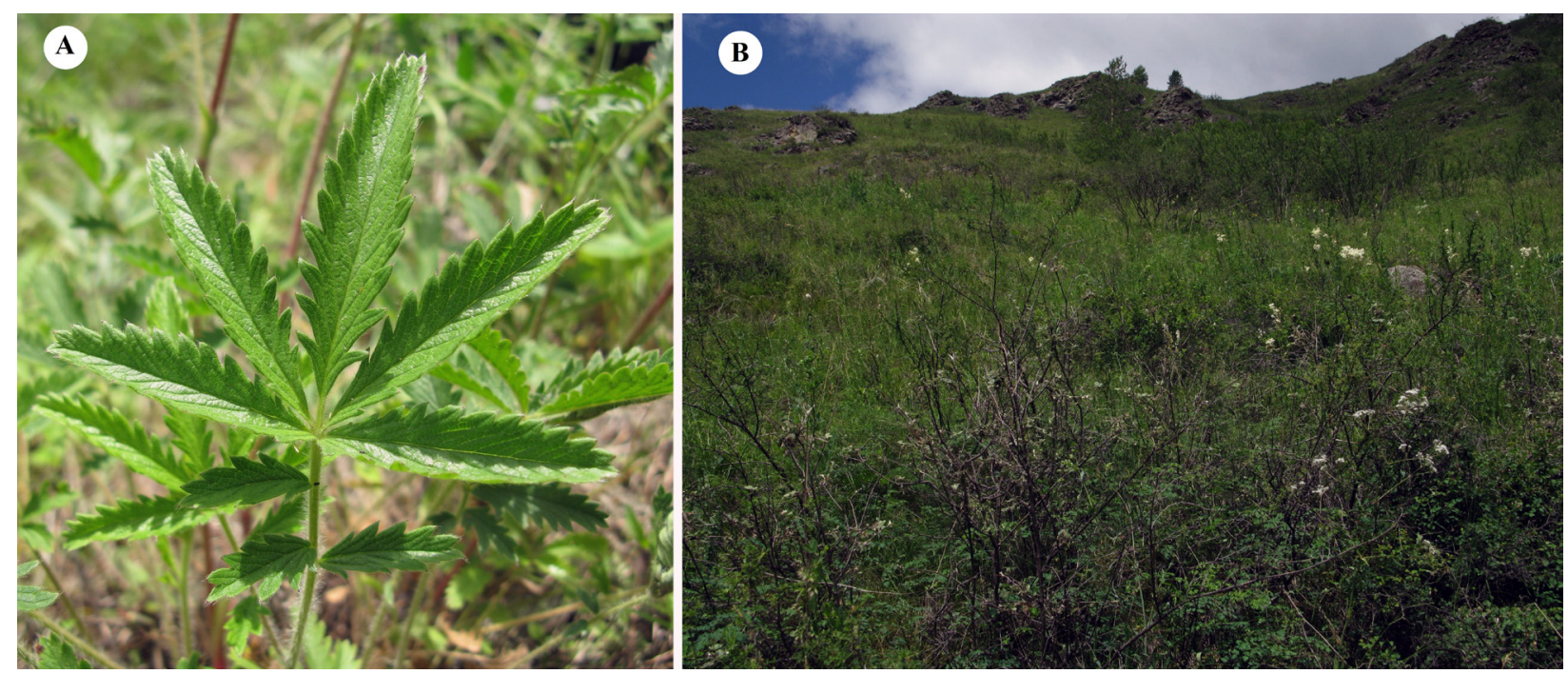

Fig. 2. Potentilla $\times$ chemalense: $\mathrm{A}-$ Basal leaf with terminal leaflet on the petiolule; $\mathrm{B}-$ the habitat of $P$. $\times$ chemalense (type locality). Photographs by Alexey Kechaykin.

\section{REFERENCES}

Danihelka J., Soják J. 2012. Potentilla $\times$ nebulosa (Rosaceae), a new intersectional nothospecies from the Altai mountains. Turczaninowia 15, 4: 5-8.

Kamelin R. V. 2005. New flora of Altai (tasks and conception of the new floristic summary). In: Flora of Altai. Vol. 1. Ed. R. V. Kamelin. Azbuka, Barnaul, 7-54 pp. [In Russian]. (Камелин P. В. Новая флора Алтая (Задачи и концепция новой флористической сводки) // Флора Алтая. Т. 1. Ред. Р. В. Камелин. Барнаул: Азбука, 2005. C. 7-54).

Kechaykin A. A., Shmakov A. I. 2014. Notes on Potentilla (Rosaceae) of Altai. 1. New hybrid from East Kazakhstan. Turczaninowia 17, 2: 29-31. DOI: 10.14258/turczaninowia.17.2.3

Kuminova A. V. 1960. Rastitelnyy pokrov Altaya [The Vegetetion of the Altai]. Ed. by V. V. Reverdatto. Siberian Branch of the USSR Academy of Sciences Publishers, Novosibirsk, 449 pp. [In Russian]. (Куминова А. В. Растительный покров Алтая. Под ред. В. В. Ревердатто. Новосибирск: Изд-во Сибирского отделения Академии наук CCCP, 1960. 449 с.). 